\title{
○矢吹今日子(岩井診療所) 小寺一興(帝京大耳當科)
}

1 . 目的

補矒器の適合では、会話音を快適レベル（MC L）で閐くために十分な利得をうること ができ、最大出力音压が不快閥值（UＣＬ）を越えないように調節できる補睖器を選択す ることが望ましい。层音性踓聘にたいする補睖器を適合する場合の考え方は確立されてい ないが、自覚䦨值上のMC Lを正常者と同等であると考えて、正常者のMCLに伝音成分

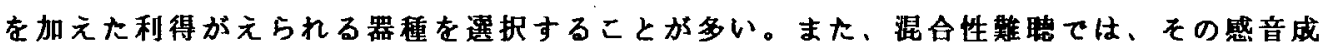
分に柱目し補俧器の特性を决定し、そこに卮音成分の值を単純に加えれば良いとの考えか゚

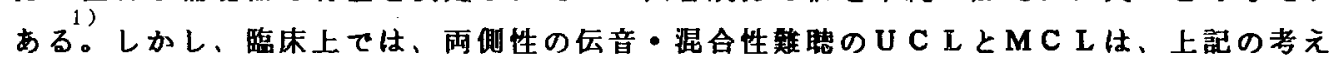

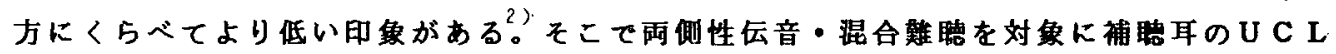
とMC L.を㛟討した。

2 . 対象と方法

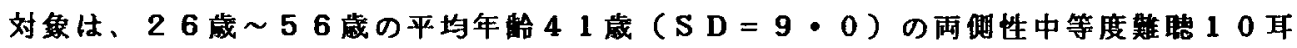

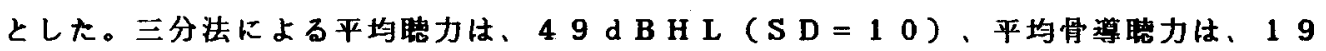
d B H L ( S D = 8、6)であった。比較のために、俧力正常者 8 名も対象とした。

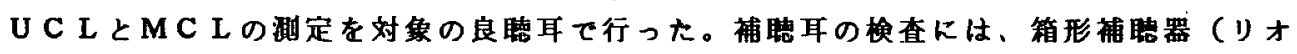
ン $56 \mathrm{~W}$ )を用いた。その周波数特性は図1に示しとおりで、低周波数帯を増幅した特性 と、低周波数帯を遮断した特性の 2 種類を用いた。

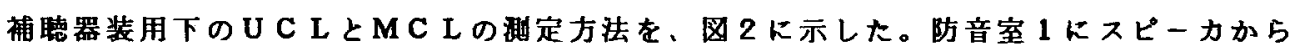

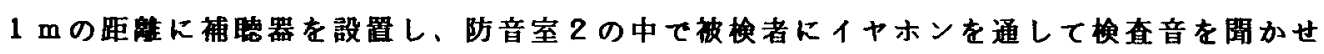
た。スピーカによる裸耳の测定では、防音室内でスピーカから検㚗音を提示し、スピーカ 前 $1 \mathrm{~m}$ の位置に着席させた被検者に聞かせた。音原には、女性の期読と男性の䐓読を録音 した 2 種類のテープを用いた。 $5 \mathrm{~d}$ B ステップで音圧を上后させて検㚗音を提示した。 U C L と M C L のレべルの㴘定には、被唡者に、自覚闌值、M C L の下限、M C L、M C Lの上限、U C L の下限、U C L の 6 段階の答えを書いたカードを手わたし、各音压ごと に感じた解答のカードを提示させた。測定は、女性の朗読・男性の䐓読について、それぞ れ 2 回ずつ行った。1 回目 2 回目ともほぼ同じ睦定結果をえたので、解析には 2 回目の值 を用いた。

3 . 結果

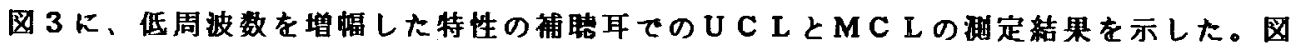
4 は、低周波数を遮断した特性の補聴耳でえられた結果を示した。補聘器の周波数特性を 変えても自覚闌値上のUＣＬとＭＣＬは変化しなかった。また、男性の朗読を聞かせたと きと女性の朗読を聞かせたときのU C LとMC Lには差を証めなかった。U C Lの值は、 約 $40 \mathrm{dBSL}$ あり、MCLの值は約 $20 \mathrm{~dB}$ 低かった。図 5 に、裸耳におけるスピーカか らの朗読にたいするU C L とMC L の濑定結果を示した。正常聘力者のU C Lの值は 62

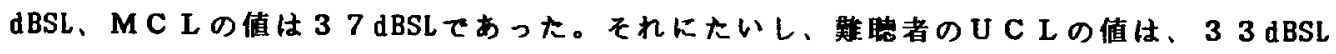
MCLの值は $17 \mathrm{dBSL}$ 著明に低かった。 


\section{4 . 考察}

层音難㯖にたいする補䁬器の適合については、考え方が確立されていない。一般には、 伝音難㯖の自覚闖值上のMC L とU C L は、正常㯖力者と同等であるとの考えがある。ま しかし、本実験結果は、兩㑡の伝音・混合難聴症例では、U C L も M C L もより低い值て

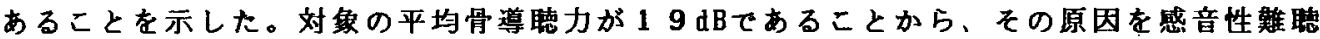
の補充現象のみで説明することはできない。後天的な環境要因が、雨側性の伝音・混合奞 愳では、U C LとMC Lを低くすることに関与していると考える。

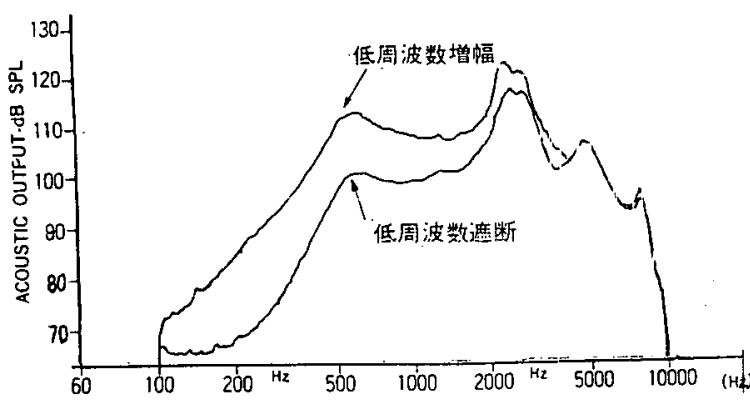

図1．周波数特性
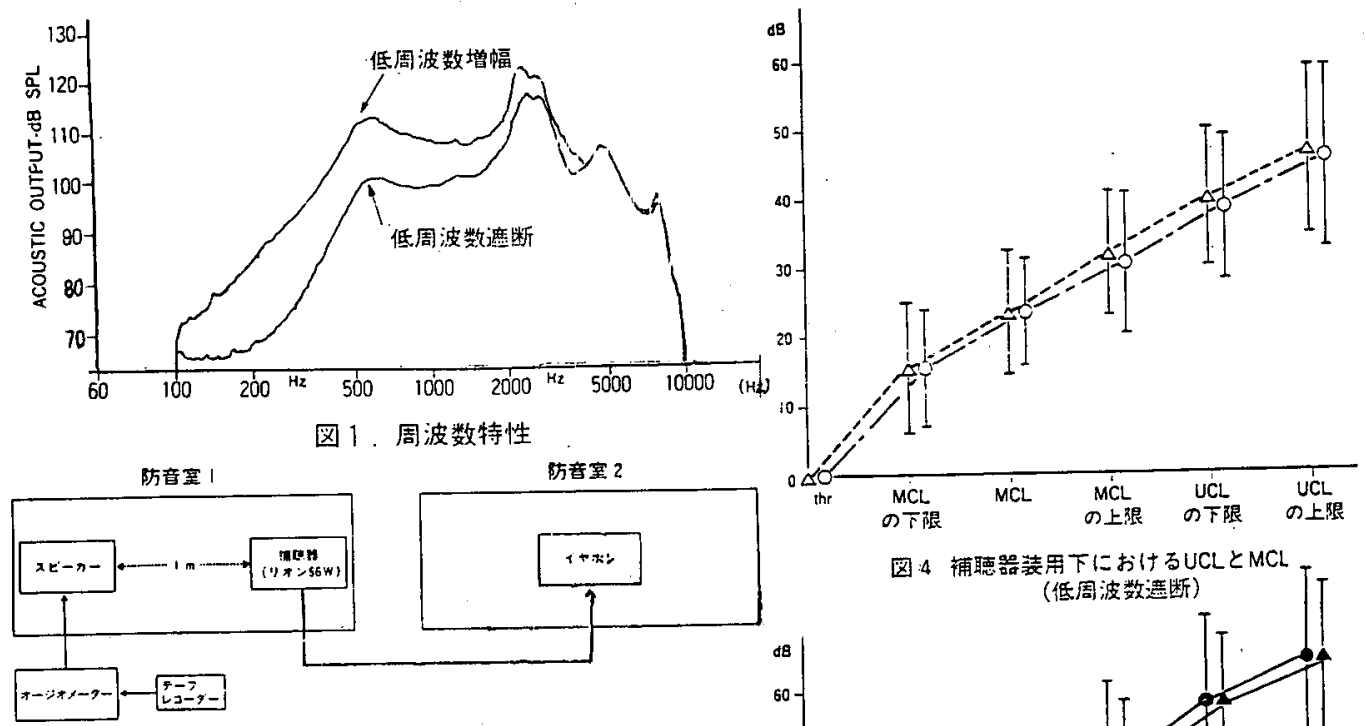

图 2 襧㯖詰装用下におけるひUCLとMCLの測定方法

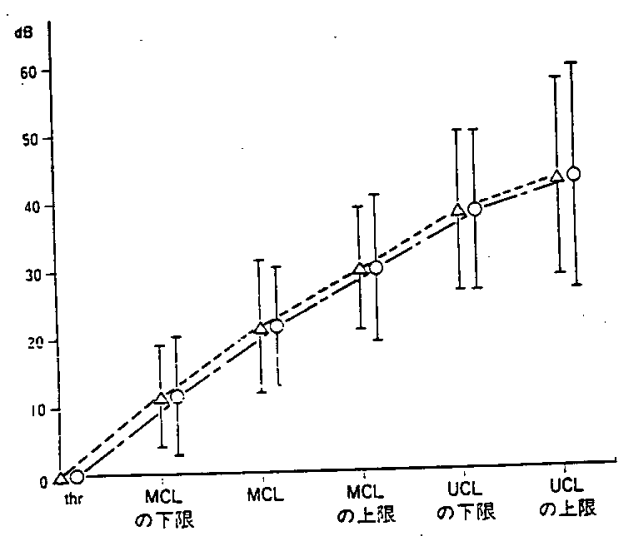

图 3 補㯖器装用下におけるUCLとMCL (低周波数增幅)

5 . 引用文献

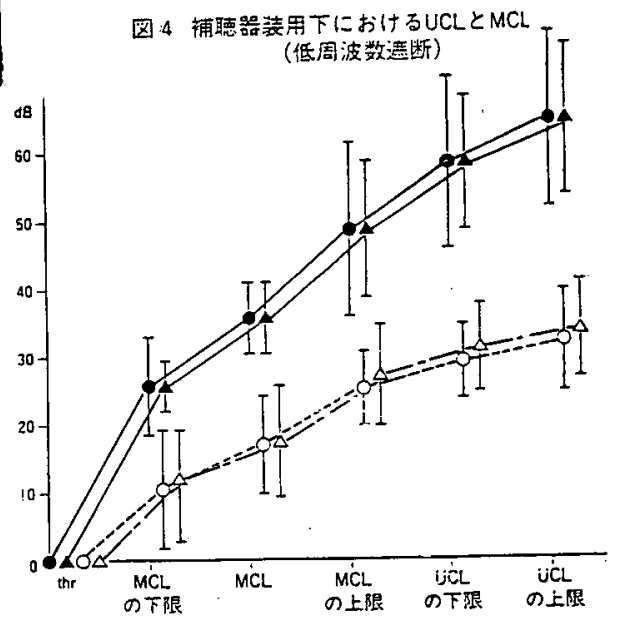

图 5 スビーカーにおけるUCLとMCL

軸は、それぞれのレベルにたい する感覚レベル（SL）を示す。 ○印は男性の朗読、 $\Delta$ 印は女性の 朗読で、正常聴力者の值を示す。 ○印は、男性の朗読、 $\Delta$ 四は女性 の朗読で、難聰者の值を示す。

1)星慎一他：层音性㯖力低下に対す百必要利得, Audiology Japan 29;535, 1986 .

2)海野佐金次：補㯖器適応検査に関する実験的研究並びに臨床的応用，日鼻耳 $72 ; 1344$, 1969. 